\title{
Modified Versus Conventional Methods for the Enumeration of Injured Microorganisms in Frozen "Mofongo"1
}

\author{
Fred Fernández $\mathrm{Coll}^{2,3}$
}

\begin{abstract}
The processes of freezing and storing frozen foods submit microorganisms to stress that results in sublethal injury of the cell. This injury translates in inability of growth under circumstances in which the cells would normally grow as in the case of the addition of selective agents to the culture media to detect or enumerate a particular organism or group of organisms. The detection and enumeration procedures must therefore provide for cellular recovery from injury before cells are exposed to selective agents. Since standard methods of microbiological analysis of foods rarely provide for injury recovery, a modification of these methods in order to consider injured cells is coming of age. Results in the present research indicated that a modified procedure for the enumeration of coliforms in frozen "mofongo" involving a recovery step with Tryptic Soy Agar before adding Violet Red Bile Agar was superior to the conventional use of Violet Red Bile Agar alone. With Staphylococcus aureus, results indicated that the modified Most Probable Number technique using Tryptic Soy Broth with $10 \% \mathrm{NaCl}$ and $1 \%$ pyruvate was superior to the conventional technique of Tryptic Soy Broth with $10 \% \mathrm{NaCl}$ and Baird-Parker Medium. The marked superiority of Baird-Parker Medium described by many previous researchers was not observed in the study.
\end{abstract}

\section{INTRODUCTION}

The principle of utilizing selectively inhibitory compounds in culture media for detection of pathogenic and indicator bacteria is based on the relative resistance of the microorganisms to such agents. Use of media containing selective agents helps isolate a desired microorganism out of a sample that contains a mixed microbial flora. However, if the cells are stressed or injured by sublethal physical or chemical treatments, selective media may not detect indicator and pathogenic bacteria; thus these media may fail to indicate the microbiological quality of the product (20).

Microbial injury is characterized by the capability of the microorganism to return to normal during a resuscitation process in which the damaged essential components are repaired $(5,20)$. The resuscitation process involves growing the microorganism in a non-selective medium for a varying number of hours before transferring it to a selective medium or

\footnotetext{
${ }^{1}$ Manuscript submitted to Editorial Board September 29, 1981.

${ }^{2}$ Research Assistant, Food Technology Laboratory Agricultural Experiment Station, Mayaguez Campus, University of Puerto Rico, Río Piedras, P. R.

${ }^{3}$ The author wishes to express his gratitude to Mrs. Isabel B. de Caloni Associate Researcher, Food Technology Laboratory, Agricultural Experiment Station, Mayagüez Campus, University of Puerto Rico, Río Piedras, P. R., for the preparation of the "mofongo" samples with the lowest possible initial bacterial counts requested for this study.
} 
before adding a selective agent to the previously non-selective medium on which the repair of injury was allowed.

Low temperatures impose stress on the microbial cells. As a result, frozen foods contain dead microorganisms as well as surviving bacterial cells, many of which may be in the injured condition (17). Since indicator and pathogenic microorganisms are detected and enumerated in selective media, the sublethal injury suffered by the cells in the process of freezing food and storing frozen food can make them susceptible to selective agents to which they normally are resistant. Therefore, before subjecting indicator and pathogenic microorganisms found in frozen foods to selective agents in the culture medium, we should allow recovery of sublethal injury in order to obtain more accurate and realistic microbial counts. This requirement may lead to a revision of existing standard methods for microbiological analysis of frozen foods.

With this need in mind, the present work was designed to study a better method to recover and enumerate sublethally injured cells of selected indicator and pathogenic bacteria inoculated into frozen "mofongo" samples.

\section{MATERIALS AND METHODS \\ PREPARATION OF "MOFONGO"}

Green plantains were purchased at the local market. They were peeled, sliced diagonally in 2 -in pieces and placed in salt water. The pieces were fried in pork lard for 7 minutes at medium heat without browning.

Twenty five grams of crushed garlic fried in $55 \mathrm{~g}$ of lard was added to one cube of chicken concentrate dissolved in $850 \mathrm{ml}$ of hot water. The mixture was allowed to boil for $10 \mathrm{~min}$. to broth. The broth was used in mashing the fried green plantain pieces in order to obtain a smoother consistency in the final product.

To prepare the "mofongo," three slices of the pre-fried plantain pieces (approx. $75 \mathrm{~g}$ ), $20 \mathrm{~g}$ crushed fried pork rind and $50 \mathrm{ml}$ hot garlic-chicken broth were used. All the above ingredients were crushed and mashed with mortar and pestle. Balls weighing $50 \mathrm{~g}$ each were shaped by hands gloved in plastic.

Each "mofongo" ball was inoculated in the center with the bacterial suspensions through sterile pipets. Samples were placed individually in cellophane boilable pouches $(15.2 \mathrm{~cm} \times 25.4 \mathrm{~cm})$, heat sealed and quick frozen at $-40^{\circ} \mathrm{C}$ in a plate freezer and stored at $-23.3^{\circ} \mathrm{C}$.

\section{INOCULATION AND MICROBIOLOGICAL ANALYSIS}

Bacterial suspensions were prepared from 24-h cultures of Escherichia coli and Staphylococcus aureus and sterile distilled water. The $E$. coli 
suspension had a concentration of 3.4 of $10^{7}$ cells $/ \mathrm{ml}$ whereas the $S$. aureus suspension possessed $1.7 \times 10^{7}$ cells $/ \mathrm{ml}$.

To each "mofongo" sample $0.5 \mathrm{ml}$ of each suspension was added. This represented an input of $1.7 \times 10^{7} \mathrm{E}$. coli and $8.5 \times 10^{6} \mathrm{~S}$. aureus cells per "mofongo" ball or $3.4 \times 10^{5} \mathrm{E}$. coli and $1.7 \times 10^{5} \mathrm{~S}$. aureus cells per gram of sample.

At various time intervals, duplicate samples were withdrawn from the freezer and each blended for 2 min with $450 \mathrm{ml}$. $0.1 \%$ peptone water. Subsequent dilutions were made with $0.1 \%$ peptone water and inoculated into the different culture media.

Coliforms (E. coli) were detected and enumerated by the solid media method with Violet Red Bile Agar (VRBA) and Violet Red Bile AgarTryptic Soy Agar (VRBA/TSA) according to standard procedures (19) and to Ordal et al. (13). Detection and enumeration of S. aureus was performed both on liquid and on solid media. The liquid media method. comprised the use of the Most Probable Number (MPN) technique with Tryptic Soy Broth (TSB) with $10 \% \mathrm{NaCl}$ according to standard procedures (19), and used TSB with $10 \% \mathrm{NaCl}$ and $1 \%$ pyruvate according to Brewer et al. (3). The solid media method was carried out according to standard procedures (19) with the Baird-Parker (BP) Medium.

\section{RESULTS AND DISCUSSION}

The results obtained with $E$. coli counts in (fig. 1) clearly demonstrate the superiority of the injury repair method (VRBA/TSA) over the conventional method (VRBA) in detecting stressed organisms. Thus, previous findings $(6,11,20)$ are confirmed with the conventional VRBA planting procedure, counts obtained after 176 days of frozen storage averaged $4.0 \times 10^{1}$ bacteria per $g$ versus $1.2 \times 10^{3}$ bacteria per $g$ when the VRBA/TSA plating procedure was used.

Several methods have been used to allow injury recovery of stressed coliforms in foods prior to enumeration $(9,14,15,16,18,20)$. All of them are based on the fact that injured coliforms and $E$. coli are susceptible to the bile salts present in the VRBA as a selective agent. This susceptibility disappears when injury is repaired, making the cells capable of normal growth in the medium.

For detecting injured coliforms in foods, either a liquid-repair method or a solid-repair method may be used. The major drawbacks of the liquidrepair method is in its application for enumeration of stressed organisms by the plating procedure. During incubation in broth, repair as well as cell multiplication can occur.

The solid-repair method is preferred for enumerating injured coliforms since it overcomes the limitations of the liquid-repair method. Since the blended sample is pour-plated with a non-selective culture medium, 
solidification of the medium quickly immobilizes the cells. The plates are then incubated to allow for repair. As the cells are immobilized, any cell multiplication during the repair phase will not influence the final count. At the end of the repair phase, the plates are overlaid with the selective planting media and incubated for the suitable time and temperature. During this time, the ingredients including the selective compounds from the selective medium will diffuse through the nonselective medium and create a selective environment.

In this way, cell injury is repaired before microorganisms are exposed to selective agents. It has been shown $(6,17,18,20)$ that these methods

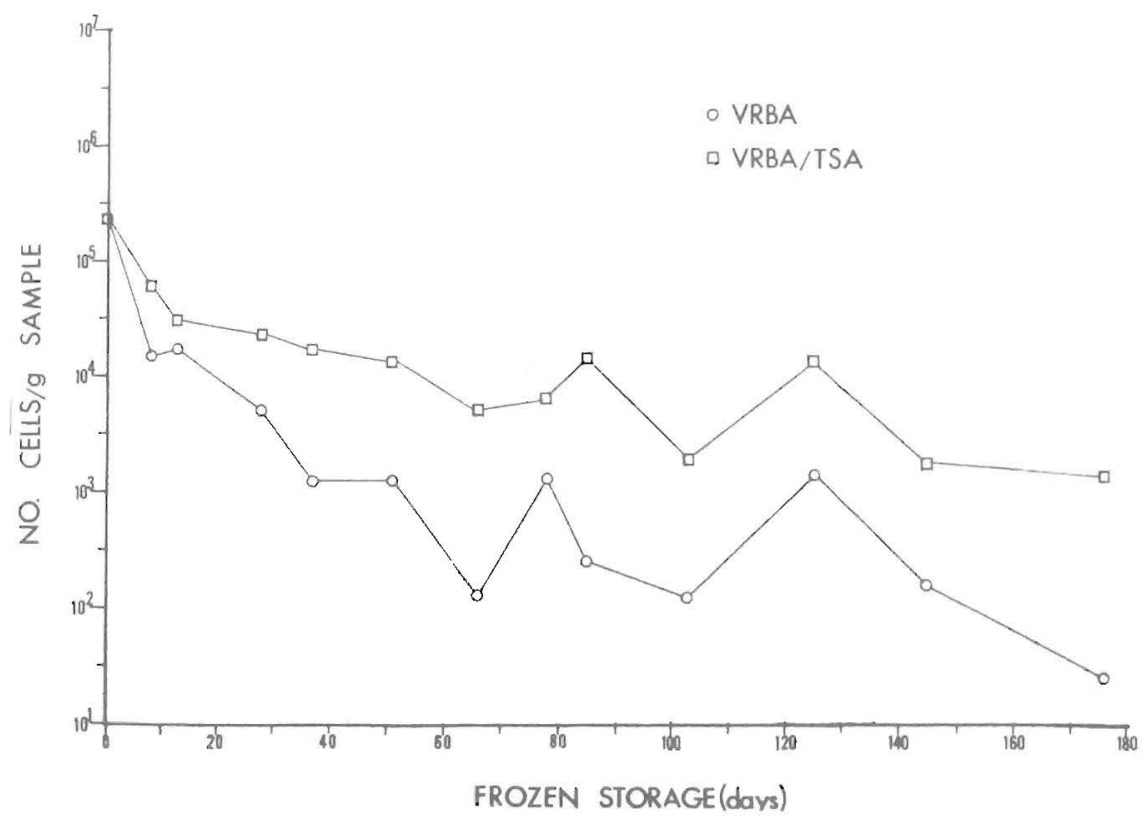

FIG. 1.-The effect of recovery media on the enumeration of injured coliforms ( $E$. coli) in frozen "mofongo".

yield higher counts than if samples are plated directly with the selective medium.

Figure 2 shows the results obtained with the $S$. aureus counts. These demonstrate that the MPN technique using TSB with $10 \% \mathrm{NaCl} / 1 \%$ Pyruvate was superior to the MPN technique using TSB with $10 \% \mathrm{NaCl}$ and to the direct plating into BP Medium plates in detecting injured staphylococci from the frozen "mofongo" samples. When we compare the counts obtained with the MPN technique using TSB with $10 \% \mathrm{NaCl}$ vs direct plating using BP Medium we notice that there is no advantage of one method over the other. There was greater variability among samples 
regarding $S$. aureus counts in all systems used to enumerate them than the variability encountered with counts of $E$. coli.

It has been suggested that the catalase activity of $S$. aureus is reduced by stress $(2,4,7,12)$. The decreased catalase activity results in an increased sensitivity to $\mathrm{H}_{2} \mathrm{O}_{2}$. Hence, accumulation of $\mathrm{H}_{2} \mathrm{O}_{2}$ during respiration, or peroxides present in the medium itself, may result in increased cell sensitivity to $\mathrm{NaCl}$, tellurite, lithium chloride or other selective agents used in culture media for the detection and enumeration of S. aureus. To obtain maximal enumeration of stressed $S$. aureus cells, it is therefore necessary to add to the medium an exogenous $\mathrm{H}_{2} \mathrm{O}_{2}$ decomposer like

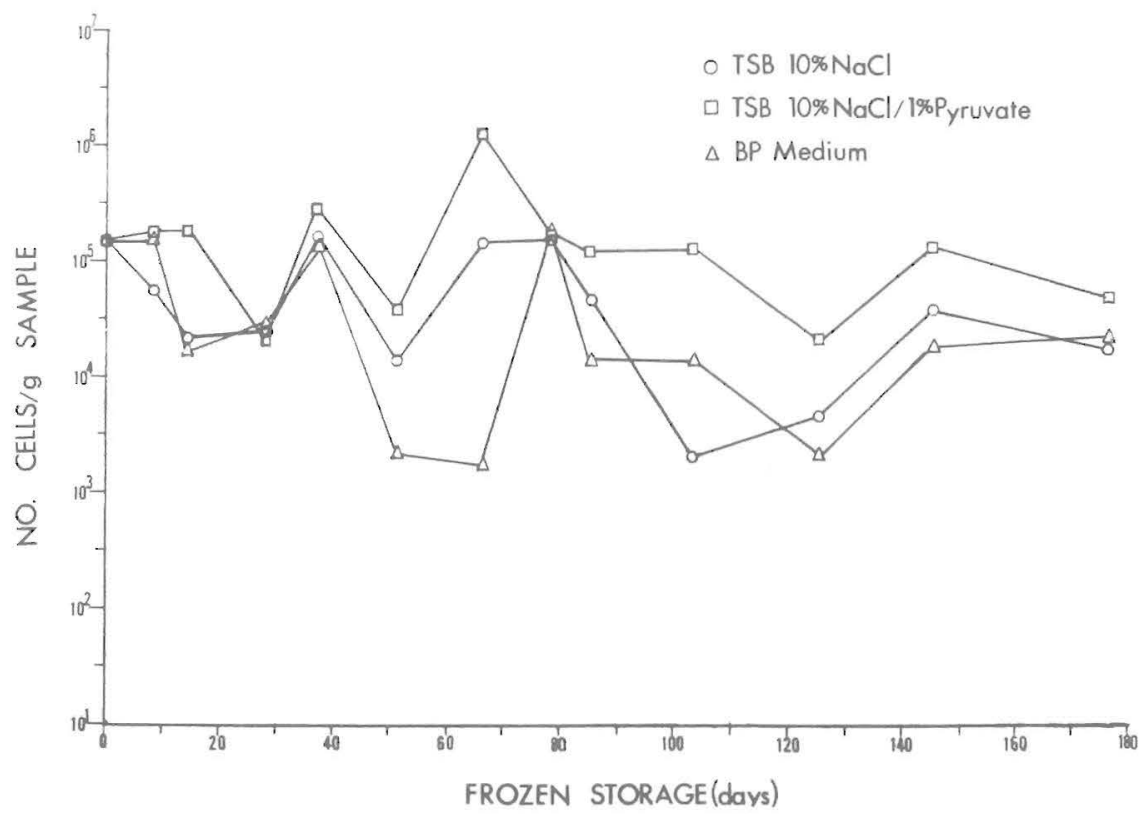

FIG. 2.-The effect of recovery media on the enumeration of injured $S$. aureus in frozen "mofongo".

catalase or sodium pyruvate (7). Brewer et al. (3) showed that catalase and pyruvate were equally effective for enumerating stressed cells of $S$. aureus. They showed that the addition of pyruvate to the culture medium may be more desirable than the addition of catalase since pyruvate is autoclavable in the medium.

Currently, direct plating into BP Medium plates is recommended for routine enumeration of $S$. aureus in foods (19) because the incorporation of pyruvate and egg yolk to the medium contributes to its efficiency in detecting stressed cells (10). Lecithin appears to be the component responsible for the stimulatory effect of egg yolk (1), presumably because 
it helps stressed $S$. aureus cells to repair the damage responsible for tellurite sensitivity. When low numbers $(<100 / g)$ of staphylococci are expected, the U.S. Department of Health, Education and Welfare (19) recommends an MPN procedure which employs TSB with $10 \% \mathrm{NaCl}$. However, the high cost of the BP Medium together with the fact that TSB with $10 \% \mathrm{NaCl}$ has been shown to be inhibitory to stressed $S$. aureus cells $(3,7,8)$, has prompted the development of alternative methods to enumerate staphylococci in foods. A number of such alternative enumeration methods have been proposed $(1,3,7,12)$.

Since the MPN technique is generally considered more efficient for enumeration of low numbers of organisms then the direct plating method, attempts have been made to improve the capacity of this procedure to detect stressed S. aureus cells. Flowers et al. (7) demonstrated that catalase addition to TSB with $10 \% \mathrm{NaCl}$ improved the enumeration of heat-stressed S. aureus cells. In a subsequent study, Brewer et al. (3) examined the effect of catalase $(200 \mathrm{U} / \mathrm{ml})$ or pyruvate $(1 \%)$ addition on enumeration of $S$. aureus by this procedure, and determined that the addition of catalase or pyruvate increased enumeration of all stressed organisms tested. Their data obtained by the MPN procedure with TSB and $10 \% \mathrm{NaCl}$ plus catalase or pyruvate correlated well with data obtained by direct plating into BP Medium.

The results obtained in the present study not only support the findings of Flowers et al. (7) and Brewers et al. (3), but also indicate that the MPN procedure using TSB with $10 \% \mathrm{NaCl}$ and $1 \%$ pyruvate may even be superior to direct plating onto BP Medium in the enumeration of stressed S. aureus cells in frozen "mofongo." Other media superior to BP for the enumeration of stressed $S$. aureus cells have been reported (1). The fact that TSB with $10 \% \mathrm{NaCl}$ and $1 \%$ pyruvate is more economical than BP Medium also makes it a very valuable alternative for enumerating stressed $S$. aureus cells.

In conclusion, current methods in food microbiology should provide for the repair of injury in stressed cells. For one reason or another, several of the commonly used methods may not be satisfactory for this purpose, so they need to be reevaluated and revised if necessary. Once this revision is accomplished and the modified methods are adopted for regulatory and for quality control purposes, any microbiological standard or criteria based upon the method being replaced must be reconsidered.

\section{RESUMEN}

La congelación y el almacenamiento en refrigeración somete a los microorganismos a una tensión que resulta en daño subletal de la célula. Este daño subletal hace que los microorganismos no crezcan bajo circumstancias en las cuales normalmente crecerían. Este es el caso 
cuando se añaden agentes selectivos a los medios de cultivo para la detección o enumeración de un organismo o un grupo de microorganismos en particular. Los procedimientos para la detección y enumeración deben, por lo tanto, proveer para reparar el daño celular antes de exponer los microorganismos a agentes selectivos. Ya que los métodos convencionales de análisis microbiológico de alimentos rara vez proveen para que se repare el daño subletal sufrido, es mandatorio que dichos métodos sean modificados para tomar en cuenta a las células lastimadas. Los resultados en el presente trabajo indicaron que un procedimiento modificado para la enumeración de coliformes fue superior al método convencional en muestras de mofongo ${ }^{4}$ congelado. El método modificado incluye un período de recuperación en Agar Triptona-Soya antes de añadir Agar Rojo Violeta Bilis, mientras que el método convencional utiliza únicamente el Agar Rojo Violeta Bilis. En la enumeración de Staphylococcus aureus, los resultados indicaron que la técnica del Número Más Probable modificada (Caldo Triptona Soya con $10 \% \mathrm{NaCl}$ y $1 \%$ piruvato) fue superior a las técnicas convencionales que utilizan Caldo Triptona-Soya con 10\% NaCl ó Medio Baird-Parker. No se observó la marcada superioridad del Medio Baird-Parker descrita por muchos investigadores.

\section{LITERATURE CITED}

1. Andrews, G. P. and Martin, S. E., 1978. Modified Vogel and Johnson Agar for Staphylococcus aureus. J. Food Prot. 41: 530-32.

2. _— and ——, 1979. Heat inactivation of catalase from Staphylococcus aureus, MF-31. Appl. Environ. Microbiol. 37: 1180-185.

3. Brewer, D. G., Martin, S. E. and Ordal, Z. J., 1977. Beneficial effects of catalase or pyruvate in a most-probable-number technique for the detection of Staphylococcus aureus. Appl. Environ. Microbiol. 34: 797-800.

4. Bucker, E. R., Martin, S. E., Andrews, G. P. and Ordal, Z. J., 1979. Effect of hydrogen peroxide and sodium chloride on enumeration of thermally stressed cells of Staphylococcus aureus, J. Food Prot. 42: 961-64.

5. Busta, F. F., 1976. Practical implications of injured microorganisms in food, J. Milk Food Technol. 39: 138-45.

6. Draughon, F. A. and Nelson, P. J., 1981. Comparisons of modified direct-plating procedures for recovery of injured Escherichia coli, J. Food Sci. 46: 1188-191.

7. Flowers, R. S., Martin, S. E., Brewer, D. G. and Ordal, Z. J., 1977. Catalase and enumeration of stressed Staphylococcus aureus cells, Appl. Environ. Microbiol. 33: $1112-117$.

8. Gray, R. J. N., Gaske, M. A. and Ordal, Z. J., 1974. Enumeration of thermally stressed Staphylococcus aureus MF-31. J. Food Sci. 39: 844-46.

9. Hartman, P. A., Hartman, P. S. and Lanz, W. W., 1975. Violet red bile 2 agar for stressed coliforms, Appl. Microbiol. 29: 537-39.

10. Lachica, R. V., 1980. Accelaerated procedure for the enumeration and identification of food-borne Staphylococcus aureus, Appl. Environ. Microbiol. 39: 17-9.

${ }^{4}$ Bolas de plátano frito y molido, cuero de cerdo tostado, caldo de pollo y condimentos. 
11. Marshall, R. T., Hartman, P. A., Cannon, R. Y., Lambeth, L., Richardson, G. H., Spurgeon, K. R., Weddle, D. B., Wingfield, M. and White, C. H., 1978. Group comparative study of VRB-2 Agar in the recovery of coliforms from raw milk, ice cream and cottage cheese, J. Food Prot. 41: 544-45.

12. Martin, S. E., Flowers, R. S. and Ordal, Z. J., 1976. Catalase: its effect on microbial enumeration. Appl. Environ. Microbiol. 32: 731-34.

13. Ordal, Z. J., Iandolo, J. J., Ray, B. and Sinskey, A. G., 1976. Detection and enumeration of injured microorganisms. In Speck, M. A. (ed) Compendium of methods for the microbiological examination of foods, pp. 163-169. American Public Health Assoc. Washington, D. C.

14. Powers, E. M. and Latt, T. G., 1979. Rapid enumeration and identification of stressed fecal coliforms, J. Food Prot. 42: 342-45.

15. Ray, B. and Speck, M. L., 1973. Discrepancies in the enumeration of Escherichia coli. Appl. Microbiol. 25: 494-98.

16. — - and ——, 1973. Enumeration of Escherichia coli in frozen samples after recovery from injury, Appl. Microbiol. 25: 499-503.

17. Speck, M. L. and Ray, B., 1977. Effects of freezing and storage on microorganisms in frozen foods: a review. J. Food Prot. 40: 333-36.

18. —_, - - and Read, R. B., Jr., 1975. Repair and enumeration of injured coliforms by a plating procedure, Appl. Microbiol. 29: 549-50.

19. U. S. Department of Health, Education and Welfare, Food and Drug Administration, 1976. Bacteriological analytical manual, U. S. Department of Health, Education and Welfare, Washington, D. C.

20. Warseck, M., Ray, B. and Speck, M. L., 1973. Repair and enumeration of injured coliforms in frozen foods, Appl. Microbiol. 26: 919-24. 